\title{
INVESTIGATION OF DISINFECTANT'S EFFECTIVENESS AS TO CONTAMINATING MICROFLORA IN SUGAR PRODUCTION
}

\author{
Nataliia Husiatynska \\ Department of sugar technologies and water treatment \\ National University of Food Technologies \\ 68 Volodymyrska str., Kyiv, Ukraine, 01601 \\ ngusyatinska@ukr.net \\ Tetiana Nechypor \\ Department of sugar technologies and water treatment \\ National University of Food Technologies \\ 68 Volodymyrska str., Kyiv, Ukraine, 01601 \\ tatkaskokun@ukr.net
}

\begin{abstract}
The article presents the results of the studies of the effectiveness of disinfection means, based on chlorinated guanidines, tetradic ammonium salts, dichlorisocyanuric acid, peracetic acid and hydrogen peroxide as to the contaminating microflora of sugar beets. There was investigated the influence of disinfectants on bacteria Bacillus subtilis, Leuconostoc mesenteroides, mycelia fungi Aspergillus niger, Penicillium chrysogenum and yeast Sacharomyses cerevisiae.

It was experimentally established, that the studied means has the high effectiveness as to most microorganisms that cause saccharose losses in the process of its extracting from beet chip and result in worsening a technological quality of semi-products of beet-sugar.

There was established the high effectiveness of modern disinfection means as to inhibiting slime-forming bacteria of Leuconostoc generis. There was proved a possibility of their use at different technological stages of beet-sugar production for preventing the development of mucous bacteriosis.

It was determined that means consumption depends on a type and extent of microbiological contamination of raw materials, semi-products, technological waters at sugar production. There were established concentrations of the studied means as to inhibiting the development of main contaminants of the microflora of raw materials and semi-products in sugar production.

There is offered to use the studied means in industrial beet-sugar production that would favor the decrease of microbial contamination of semi-products and the increase of a sugar output from a raw material unit.
\end{abstract}

Keywords: sugar beets, disinfectant, dextran, diffusion apparatus, mucous bacteriosis.

\section{Introduction}

The course of microbiological process at extracting saccharose of beet chip causes its disintegration, creation of a series of acids, dextran that results in essential losses of saccharose at production, worsening of the white sugar quality and in separate cases - the decrease of productivity of a plant. Microbiological contamination essentially worsens the quality of semi-products and ready sugar, especially as a result of forming organic acids, increase of chromaticity, foaming in juice and so on [1].

The amount of microorganisms in diffusion juice depends on many factors and according to different researchers, can be from $1 \times 10^{6}$ to $1 \times 10^{8} \mathrm{CFU}$ in $1 \mathrm{~cm}^{3}$ [2-4]. The great amount of sporiferous bacteria were found in diffusion juice: Bacillus subtilis, B. mesentericum, B. megatherium, $B$. mycoides, $B$. circulans, $B$. stearothermophilus, which activity is manifested in acid and gas formation, disintegration of saccharose into reducing substances, resulted in complications in the process of purification, filtration and crystallization of saccharose [3, 4].

The most spread type of bacterial diseases of sugar beets is mucous bacteriosis. As a result of injuring edible roots, dextran forms in sugar beet juice, its presence causes not only direct losses of saccharose, but also essential problems at production, so results in financial losses of an enterprise [5]. Dextran is produced by bacteria of Leuconostoc, Lactobacillus 
and Streptococcus genera. The most spread type of slime-forming bacteria, occurred at sugar plants, is Leuconostoc mesenteroides [6]. Dextran creation by bacteria of Leuconostoc mesenteroides generis takes place as a result of saccharose disintegration, analogous to enzymatic inversion save that glucose is polymerized in dextran, and fructose is used for nourishing bacteria [7].

Dextran is a polyglucan, which size changes from the low-molecular (soluble) to high-molecular (insoluble). At the same time its solubility depends on the structural construction of a macromolecule: the higher content of $\alpha-(1 \rightarrow 6)$ connections, the more solubility. And vice versa, the higher percent of $\alpha-(1 \rightarrow 3)$ connections in a polymer, the less solubility in water [8]. Just the presence of soluble dextran in juices and semi-products causes most technological problems: the effectiveness of juice purification decreases, filtrating-sediment properties of residue worsen, evaporation speed decreases, heat transmission diminishes and so on [9, 10]. It finally results in decelerating the crystallization process, increase of duration of boiling massecuites that causes the decrease of factory capacities [11]. The aforesaid results of microbiological processes at producing sugar testify to the topicality of control and elaboration of arrangements as to their prevention and elimination, and also provision of sanitary conditions of production for ready products according to SSU requirements [12].

For decreasing losses of saccharose from microbiological disintegration, it is expedient to use disinfection means at different production stages, especially: at rinsing roots after washing, for processing juice-chip mixture in the diffusion apparatus, nutritious water and so on. Existent differences in the technological equipment of sugar plants need a differentiated approach to disinfection at separate stages of the technological process, especially: equipment, technological waters, intermediate products.

The aim of the researches was to study the effectiveness of disinfection means, based on different active substances, namely: chlorinated guanidines, tetradic ammonium salts, dichlorisocyanuric acid, peracetic acid and hydrogen peroxide as to inhibiting the vital activity of microorganisms that favor most loses at the stage of getting diffusion juice in sugar-beet production.

\section{Materials and Methods}

Research objects were: 4 modern biocide means: based on chlorinated guanidine («HSG dez 2»), tetradic ammonium salts («HSG dez 3»), dichlorisocyanuric acid («HSG dez 4»), peracetic acid and hydrogen poroxide ( $« \mathrm{HSG}$ dez $5 »)$.

The studied means belong to III class of moderately dangerous substances by acute toxicity parameters, according to SS 12.1.007. The disinfection means «HSG dez 2»-transparent liquid, colorless or with light opalescence. The active substance of «HSG dez 2» is polyhexamethylenebiguanidine hydrochloride in the amount no less $15 \%$. The disinfection means «HSG dez 3»-transparent liquid from colorless to light yellow color. The active substance of it is tetradic ammonium compounds in the amount no less $40 \%$. The disinfection means «HSG dez $4 »$ is a solid substance that looks as tablets, granules or powder. Its active substance is sodium salt of dichlorisocyanuric acid, no less $80,0 \%$. The disinfection means «HSG dez 5» - transparent liquid from colorless to light yellow color. Its active substance is peracetic acid in the amount no less $12 \%$ and hydrogen peroxide no less $18 \%$.

There were used the following concentrations of working solutions (by the active substance content): «HSG dez 2»-0,001, 0,002, 0,003 and 0,004 \%, «HSG dez 3»-0,0005, 0,00075, 0,001, 0,002 and $0,004 \%$, «HSG dez 4»-0,0002, 0,0004, 0,0008 and 0,001\%, «HSG dez 5»-0,001, $0,002,0,004$ and $0,008 \%$.

The effectiveness of disinfection means was studied on pure cultures of microorganisms. The choice of test-cultures was based on the analysis of the contaminating microflora of raw materials, semi-products and technological waters in sugar production, taking into account the negative influence of products of microbial metabolism on the course of technological processes and white sugar quality. 
We established that a series of microorganisms belongs to the contaminating microflora of diffusion juice and technological waters: yeast of Saccharomyces, Torulopsis genera, bacteria Bacillus subtilis, B. mesentericus, B. megatherium, Escherichia coli, Aerobacter aerogenes, Leuconostoc mesenteroides. At processing raw materials, injured by clamp mould, spores of micromycetes of Fusarium, Botrytis, Mucor, Penicillium, Aspergillus, Trichotecium, Verticillium genera, can penetrate diffusion juice.

Thus, the following microorganisms were chosen as test-cultures: ammonifying bacteria Bacillus subtilis, slime-forming bacteria Leuconostoc mesenteroides, mycelium fungi Aspergillus niger, Penicillium chrysogenum and yeast Sacharomyses cerevisiae.

The studies were realized under laboratory conditions. For determining the sensitivity of the microflora, typical for diffusion juice and effect of biocide preparations on it, there was used the method of "holes in agar layer" [13]. Cultivation of microorganisms was realized on the following nutrient mediums: a) meat infusion agar (MIA) with inclusion pure cultures of microorganisms (B. subtilis, L. mesenteroides), b) medium with wort agar with pure cultures of micromycetes $A$. niger, $P$. chrysogenum and yeast $S$. cerevisiae. Nutrient mediums with a correspondent culture of microorganisms were poured in sterile Petri dishes. After stiffing the nutrient medium, holes were made at distance 1,5 - 2,0 cm from a dish edge using a sterile drill. Water solutions of antimicrobial preparations with different concentrations were introduced to them.

Conclusions about the effectiveness of disinfectants at a certain solution concentration were made according to the availability of areas of stunted growth of microorganisms. No areas of stunted growth indicates that the studied culture is insensitive to the action of the product at the specified concentration. With the zone diameter of $15 \mathrm{~mm}$ we believe that microorganisms have a small degree of sensitivity to the corresponding concentration of the product, with the zone diameter of 15 to $25 \mathrm{~mm}$ the average degree of sensitivity is indicated. Availability of the zone with diameter greater than $25 \mathrm{~mm}$ indicates a high degree of sensitivity of microorganisms to the concentration of the antimicrobial agent.

\section{Results}

3. 1. Analysis of effectiveness of disinfection cultures as to test-cultures of microorganisms The results of studying the effectiveness of disinfection means on separate types of microorganisms, present in feedwater and beet chip, are presented in Tables 1-4 and on Fig. 1-3.

\section{Table 1}

Sensitivity level of test-cultures of microorganisms to disinfection means based on chlorinated guanidines «HSG dez 2»

\begin{tabular}{ccccc}
\hline & \multicolumn{3}{c}{ Diameter of zone of effect of antimicrobial means, $\mathbf{m m}$} \\
\cline { 2 - 5 } Cultures of microorganisms & \multicolumn{3}{c}{ Consumption of active substance, $\mathbf{g}$} \\
\cline { 2 - 5 } & $\mathbf{0 , 0 0 1}$ & $\mathbf{0 , 0 0 2}$ & $\mathbf{0 , 0 0 3}$ & $\mathbf{0 , 0 0 4}$ \\
\hline B. subtilis & 20 & 23 & 26 & 42 \\
L. mesenteroides & 27 & 34 & 40 & 44 \\
S. cerevisiae & 33 & 38 & 40 & 40
\end{tabular}

The analysis of the results of the conducted researches (tables 1-4) testifies to the high effectiveness of the studied disinfection means «HSG dez 2», «HSG dez 3», «HSG dez 4» and «HSG dez 5» comparing with the bacterial microflora, yeast and micromycetes, present in raw materials, technological water, semi-products of beet-sugar production. 
Table 2

Sensitivity level of test-cultures of microorganisms to disinfection means based on tetradic ammonium salts «HSG dez 3»

\begin{tabular}{cccccc}
\hline & \multicolumn{5}{c}{ Diameter of zone of effect of antimicrobial means, mm } \\
\cline { 2 - 6 } Cultures of microorganisms & \multicolumn{5}{c}{ Consumption of active substance, $\mathbf{g}$} \\
\cline { 2 - 6 } & $\mathbf{0 , 0 0 0 5}$ & $\mathbf{0 , 0 0 0 7 5}$ & $\mathbf{0 , 0 0 1}$ & $\mathbf{0 , 0 0 2}$ & $\mathbf{0 , 0 0 4}$ \\
\hline B. subtilis & 18 & 23 & 25 & 27 & 30 \\
L. mesenteroides & 12 & 18 & 21 & 28 & 30 \\
S. cerevisiae & 19 & 22 & 24 & 26 & 28 \\
A. niger & 9 & 12 & 19 & 23 & 27
\end{tabular}

Table 3

Sensitivity level of test-cultures of microorganisms to disinfection means based on dichlorisocyanuric acid «HSG dez 4»

\begin{tabular}{|c|c|c|c|c|}
\hline \multirow{3}{*}{ Cultures of microorganisms } & \multicolumn{4}{|c|}{ Diameter of zone of effect of antimicrobial means, $\mathbf{m m}$} \\
\hline & \multicolumn{4}{|c|}{ Consumption of active substance, $\mathrm{g}$} \\
\hline & 0,0002 & 0,0004 & 0,0008 & $\mathbf{0 , 0 0 1}$ \\
\hline B. subtilis & $\begin{array}{l}16 \text { (28 - growth } \\
\text { inhibition) }\end{array}$ & $\begin{array}{c}20 \text { (30 - growth } \\
\text { inhibition) }\end{array}$ & $\begin{array}{l}23 \text { (33 - growth } \\
\text { inhibition) }\end{array}$ & $\begin{array}{l}25 \text { (34- growth } \\
\text { inhibition) }\end{array}$ \\
\hline L. mesenteroides & 18 & 23 & 28 & 33 \\
\hline S. cerevisiae & 30 & 5 Colonies & \multicolumn{2}{|c|}{ sterile } \\
\hline A. niger & 14 & 22 & 2 colonies & sterile \\
\hline
\end{tabular}

Table 4

Sensitivity level of test-cultures of microorganisms to disinfection means based on peracetic acid and hydrogen peroxide «HSG dez 5»

\begin{tabular}{ccccc}
\hline & \multicolumn{4}{c}{ Diameter of zone of effect of antimicrobial means, $\mathbf{m m}$} \\
\cline { 2 - 5 } Cultures of microorganisms & \multicolumn{4}{c}{ Consumption of active substance, $\mathbf{g}$} \\
\cline { 2 - 5 } & $\mathbf{0 , 0 0 1}$ & $\mathbf{0 , 0 0 2}$ & $\mathbf{0 , 0 0 4}$ & $\mathbf{0 , 0 0 8}$ \\
\hline B. subtilis & 34 & 46 & 48 & sterile \\
L. mesenteroides & 15 & 20 & 26 & 34 \\
S. cerevisiae & 18 & 20 & 29 & 36 \\
A. niger & 13 & 17 & 21 & 26
\end{tabular}

At to the means «HSG dez 2», based on chlorinated guanidines, it is active as to different groups of microorganisms, including micromycetes and slime-forming bacteria at consumption $0,001 \ldots 0,002 \%$.

There must be noted the high effectiveness of the presented means as to slime-forming bacteria (Tables 1-4, Fig. 3, b). Thus, at consuming disinfection means «HSG dez 2» and «HSG dez $3 »$ in $0,001 \ldots 0,002 \%$ the zone, delaying the growth of slime-forming bacteria Leuconostoc mesenteroides is $27 . .34 \mathrm{~mm}$ and $21 \ldots .28 \mathrm{~mm}$, respectively, that testifies to their high effectiveness. Means, based on peracetic acid and hydrogen peroxide, are also effective as to slime-forming bacteria. At consuming disinfection means «HSG dez 5» 0,004...0,008\% the zone, delaying the growth is $26 . .34 \mathrm{~mm}$. 
The analysis of the results of the conducted researches (Table 3) testifies to the high effectiveness of the chosen means as to the bacterial microflora of beet-sugar production. The nature of the poisoning effect of chemical compounds, based on active chlorine, is connected with oxidation processes in the protoplasm of a microbial cell that results in its death. Thus, at using disinfection means «HSG dez 4» in diapason of active substance consumption $0,0002 \ldots 0,0004 \%$ there is observed death of vegetative forms of mesophilic sporiferous bacteria $B$. subtilis, and also yeast $S$. cerevisiae. For attaining the analogous effect of decontamination as to slime-forming bacteria Leuconostoc mesenteroides and micromycetes $A$. Niger, consumption of the active substance must be increased to $0,0004 \ldots 0,0008 \%$.

Thus, according to the results of the conducted experimental studies, it is necessary to note the high effectiveness of the chosen means «HSG dez 2», «HSG dez 3», «HSG dez 4» and «HSG dez $5 »$ as to the wide spectrum of microorganisms. At that these means are effective as to inhibiting the development of slime-forming bacteria of Leuconostoc generis.

According to the results of the conducted studies, it was established, that the effective dose of a disinfectant is determined by the type of contaminating microflora of raw materials and semi-products of sugar production. Although, under industrial conditions raw materials contain the wide spectrum of micromycetes and bacteria, average rational doses that provide decontamination as $80-90 \%$ are used at disinfection.

Taking into account the results of the studies of the effect of the means as main contaminants of beet-sugar production, it was established, that rational concentrations in average correspond to:

- «HSG dez 2» - 0,002 ..0,003 \%;

- «HSG dez 3»-0,001...0,002\%;

$-\ll$ HSG dez 4»-0,0004...0,0008\%;

- «HSG dez 5»-0,004...0,006\%.

Fig. 1-3 graphically illustrate the results of disinfection effect of the means, based on: dichlorisocyanuric acid (Fig. 1), chlorinated guanidines (Fig. 2), peracetic acid and hydrogen peroxide (Fig. 3).
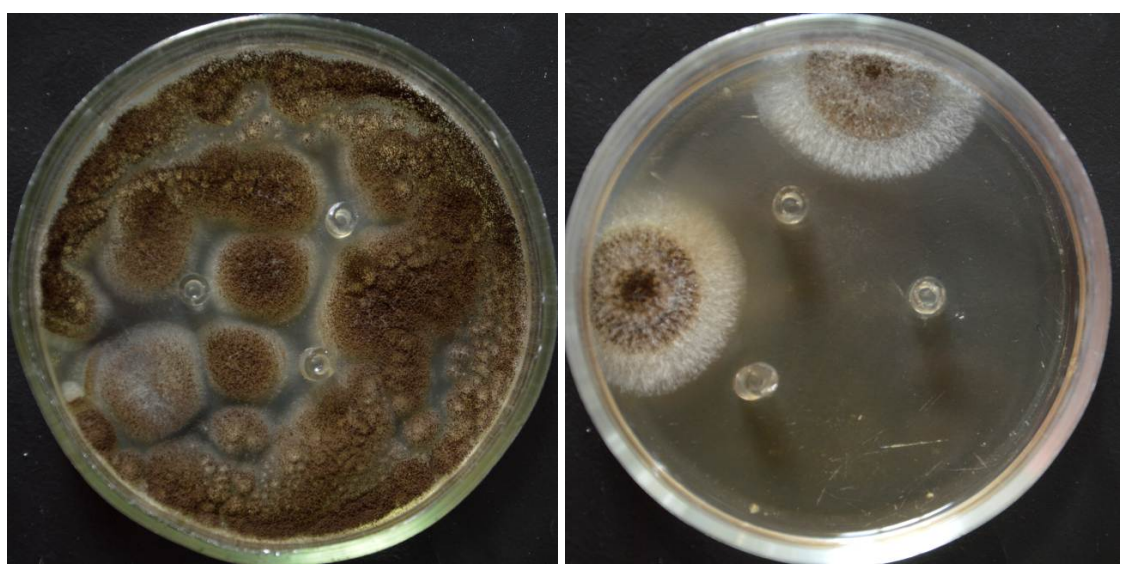

Fig. 1. Effect of the mean «HSG dez 4» with concentrations 0,0002 and $0,0008 \%$ on micromycetes $A$. niger

It must be noted that at using «HSG dez 4» there were observed not only distinctly separated zones, delaying the microorganisms' growth, but also inhibition of the growth of cultures along the whole dish. Eucaryotes (micromycetes and yeasts) demonstrated the higher sensitivity to the effect of this means than bacterial cultures that can be explained by differences of the structure of a cellular wall and mechanism of the influence of chlorine compounds on microbial cells.

The presence of the high bactericide effect allows to recommend the studied means for processing transport-washing water, water for rinsing edible roots, for processing juice-chip mixture at extracting saccharose of beet chip and at other production stages that need disinfection. 
Reports on research projects
(2018), «EUREKA: Life Sciences»

Number 5
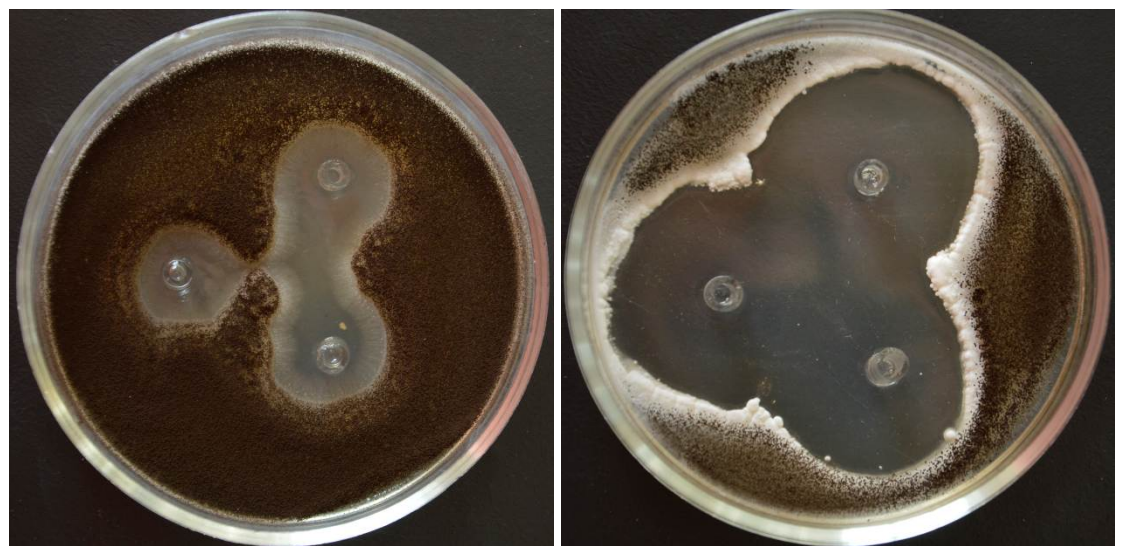

Fig. 2. Effect of the means «HSG dez $2 »$ with concentrations 0,005 and $0,02 \%$ on micromycetes $A$. niger
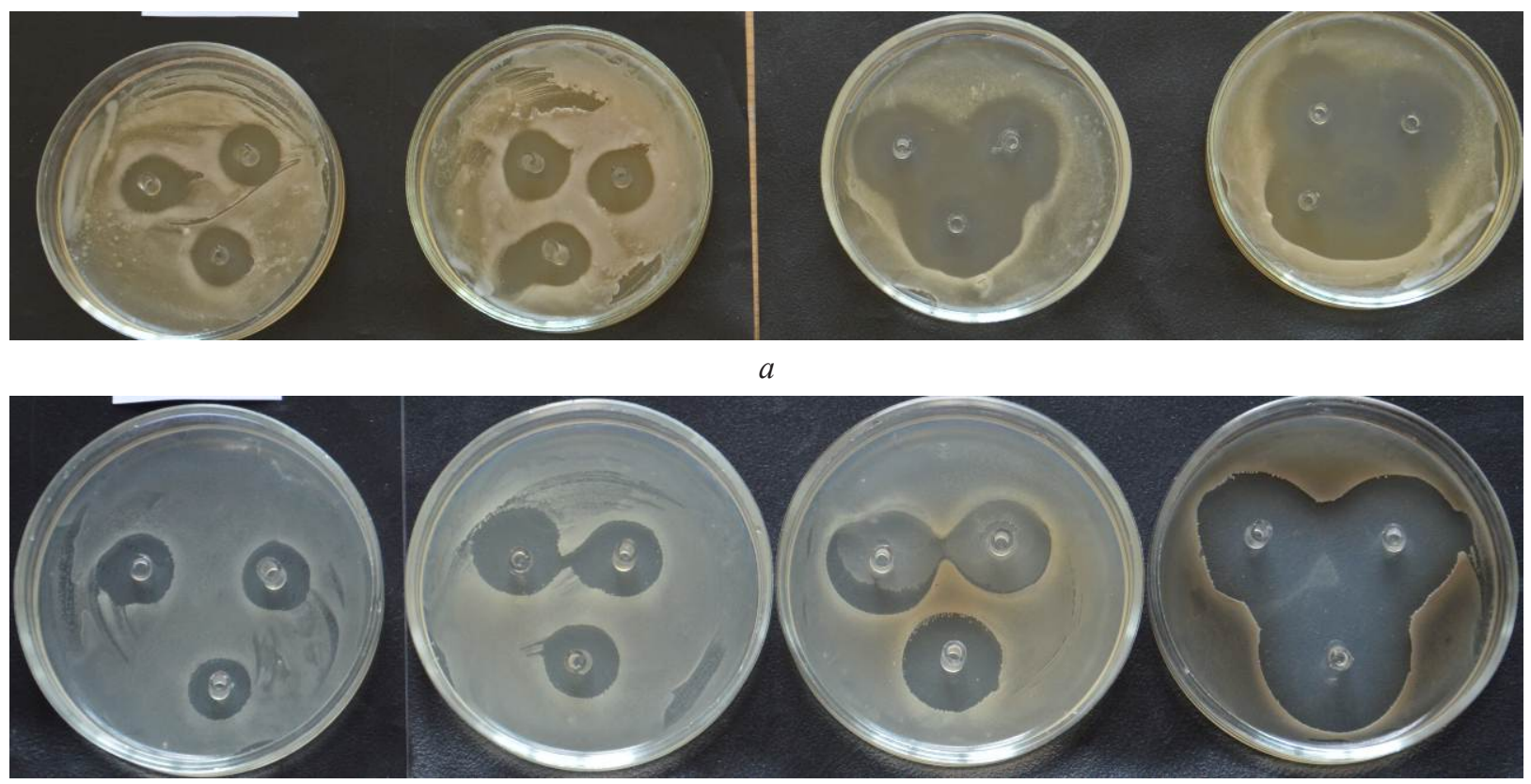

$b$

Fig. 3. Effect of the means «HSG dez 5» with concentrations $0,001,0,002,0,004$ and $0,008 \%$ on microorganisms: $a$-effect on $S$. cerevisiae; $b$ - effect on $L$. mesenteroides

\section{Conclusions}

The conducted studies demonstrated the high effectiveness of using modern biocide means, namely - based on chlorinated guanidines («HSG dez 2»), tetradic ammonium salts («HSG dez 3»), dichlorisocyanuric acid («HSG dez 4»), peracetic acid and hydrogen peroxide («HSG dez 5»), for decreasing microbial contamination at sugar production.

It was established, that the studied means have the high effectiveness as to most microorganisms that cause losses of saccharose in the process of its extracting from beet chip and result in worsening a technological quality of semi-products of beet-sugar. There was established the high effectiveness of modern disinfection means as to inhibiting slime-forming bacteria.

The practical value of the conducted studies is in establishing the rational concentrations of the studied means as to inhibiting the development of main contaminants, based on which there are elaborated technological regulations of introducing the studied disinfectants in sugar production. 


\section{References}

[1] Husyatynska, N. A., Teterina, S. M., Kasian, I. M., Husiatynskyi, M. V. (2010). Analiz mikrobiolohichnykh protsesiv ta sposobiv yikh pryhnichennia pry zberihanni tsukrovykh buriakiv. Kharchova promyslovist, 9, 36-38.

[2] Husyatynska, N. A. (2006). Pytannya mikrobiolohichnoho kontrolyu ta vyboru antyseptyka pry ekstrahuvanni tsukrozy. Tsukor Ukainy, 6, 12-15.

[3] Gusyatynska, N., Nechypor, T. (2017). Inhibition of microbiological processes in sucrose extraction. Ukrainian Food Journal, 6 (3), 504-513. doi: http://doi.org/10.24263/2304-974x-2017-6-3-10

[4] Noori, S., Naghavi, N. S., Mohammadi Sichani, M., Gol Gol Jam, M., Zia, M. A. (2014). Identification and biological control of microbial agents causing corruption of stored sugar beets in sugar production industry. Journal of Sugar Beet, 29 (2), 79-85.

[5] Egglston, D., Dilkz, E., Blowers, M., Winters, K. (2017). Uspeshnoye primeneniye dekstranazy na sveklopererabatyvayushchikh zavodakh. Sakhar, 3, 30-40.

[6] Patel, K. K., Shah, F., Dwivedi, M. (2018). Exopolysaccharide (EPS) Producing Isolates from Sugarcane Field Soil and Antibacterial Activity of Extracted EPSs. Acta Scientific Microbiology, 1 (4), 6-13. doi: http://doi.org/10.31080/asmi.2018.01.0032

[7] Bukhari, M. M., Salem, El Kh., Osman, A., Hegazi, S. E. F. (2015). Investigations of the influence of dextran on sugar cane quality and sugar cane processing in Kenana sugar factory. Journal of Chemical and Pharmaceutical Research, 7 (4), 381-392.

[8] Soliman E.-S. A. A.-R. (2007). Investigations on the influence of dextran during beet sugar production with special focus on crystal growth and morphology: dissertation doctor of engineering. Berlin, 109.

[9] Bratiuk, D. V., Husiatynska, N. A., Lipiets, A. A., Muravska, K. V. (2010). Udoskonalennia tekhnolohii ochyshchenia dyfuziinoho soku pry pereroblenni buriakiv, urazhenykh slyzystym bakteriozom. Visnyk ChDTU, 2, 132-135.

[10] Husiatynska, N. A., Nechypor, T. M. (2016). Tekhnolohichni aspekty pereroblennia buriakiv, urazhenykh slyzystym bakteriozom. Tsukor Ukrany, 11-12 (131-132), 53-58.

[11] Hein, W., Rosner, G., Emerstorfer, F. (2008). Measures to prevent operational disturbances caused by dextran. Sugar Industry, 133 (3), 135-143.

[12] Borysiuk, P. H., Halatsan, L. A. (2018). Harmonizatsiia ukrainskykh standartiv z mizhnarodnymy i yevropeiskymy. Tsukor Ukrainy, 1, 23-29.

[13] Hrehirchak, N. M. (2009). Mikrobiolohiia kharchovykh vyrobnytstv: Kyiv: NUKhT, 302. 